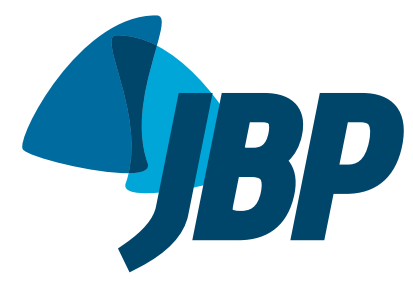

\title{
The value of antibody-coated bacteria in tracheal aspirates for the diagnosis of ventilator-associated pneumonia: a case-control study
}

\author{
Otavio Tavares Ranzani', Daniel Neves Forte ${ }^{2}$, Antonio Carlos Forte ${ }^{3}$, \\ Igor Mimica ${ }^{3}$, Wilma Carvalho Neves Forte ${ }^{3}$
}

1. Unidade de Terapia Intensiva Respiratória, Divisão de Pneumologia, Instituto do Coração, Hospital das Clínicas, Faculdade de Medicina, Universidade de São Paulo, São Paulo (SP) Brasil.

2. Unidade de Terapia Intensiva, Disciplina de Emergências Clínicas, Hospital das Clínicas, Faculdade de Medicina, Universidade de São Paulo, São Paulo (SP) Brasil.

3. Disciplina de Imunologia, Departamento de Ciências Patológicas, Faculdade de Ciências Médicas da Santa Casa de São Paulo, São Paulo (SP) Brasil.

Submitted: 28 September 2015. Accepted: 19 April 2016

Study carried out in the Intensive Care Unit, Santa Casa de Misericórdia de São Paulo, São Paulo (SP) Brasil.

\begin{abstract}
Objective: Ventilator-associated pneumonia (VAP) is the leading type of hospital-acquired infection in ICU patients. The diagnosis of VAP is challenging, mostly due to limitations of the diagnostic methods available. The aim of this study was to determine whether antibody-coated bacteria (ACB) evaluation can improve the specificity of endotracheal aspirate (EA) culture in VAP diagnosis. Methods: We conducted a diagnostic case-control study, enrolling 45 patients undergoing mechanical ventilation. Samples of EA were obtained from patients with and without VAP (cases and controls, respectively), and we assessed the number of bacteria coated with FITC-conjugated monoclonal antibodies ( IgA, IgM, or IgG) or an FITC-conjugated polyvalent antibody. Using immunofluorescence microscopy, we determined the proportion of ACB among a fixed number of 80 bacteria. Results: The median proportions of ACB were significantly higher among the cases ( $n=22)$ than among the controls ( $n=23)-\lg A(60.6 \%$ vs. $22.5 \%), \lg M(42.5 \%$ vs. $12.5 \%)$, IgG (50.6\% vs. $17.5 \%)$, and polyvalent $(75.6 \%$ vs. $33.8 \%)-p<0.001$ for all. The accuracy of the best cut-off points for VAP diagnosis regarding monoclonal and polyvalent ACBs was greater than $95.0 \%$ and $93.3 \%$, respectively. Conclusions: The numbers of $A C B$ in EA samples were higher among cases than among controls. Our findings indicate that evaluating $A C B$ in EA is a promising tool to improve the specificity of VAP diagnosis. The technique could be cost-effective and therefore useful in lowresource settings, with the advantages of minimizing false-positive results and avoiding overtreatment.
\end{abstract}

Keywords: Pneumonia, ventilator-associated/diagnosis; Immunohistochemistry; Fluorescent antibody technique; Antibodies, bacterial/analysis; Trachea/microbiology; Intensive care units.

\section{INTRODUCTION}

Ventilator-associated pneumonia (VAP) affects approximately $25 \%$ of patients submitted to mechanical ventilation, with an incidence of 2-16 episodes/1,000 hospital admissions. ${ }^{(1,2)}$ Although VAP is associated with high mortality, the attributable mortality can be low depending on the case mix and adjustments. ${ }^{(3-6)}$ In addition, VAP contributes to multiple organ failure in debilitated patients, prolonged hospitalization and increased health-associated costs. ${ }^{(7,8)}$

The diagnosis of VAP is challenging, and guidelines suggest that a clinical approach, a microbiologic approach, or both should be employed.(4,9-11) Clinical criteria alone have been shown to have low specificity, because several other pathologies seen in the ICU can mimic VAP, ${ }^{(11-13)}$ although their high sensitivity is useful for raising the suspicion of pneumonia. ${ }^{(9,12)}$ Conversely, clinicians cannot rely only on microbiologic results, because it can be difficult to deal with false-positives (e.g., to differentiate between tracheal colonization and infection) ${ }^{(9)}$ and false-negatives (e.g., culture-negative results due to previous antibiotic use) when interpreting a respiratory tract culture result. $(4,6,9)$ Combining the two approaches (clinical and microbiological) seems to improve the diagnostic accuracy. ${ }^{(4,9,14)}$

In medical practice, invasive and noninvasive techniques are used in order to obtain samples from the lower respiratory tract for microbiological evaluation. Recently, a clinical trial ${ }^{(15)}$ and a meta-analysis both showed that there are no differences between invasive and noninvasive techniques regarding main outcomes. ${ }^{(16)}$ Although invasive methods have higher specificity than does the collection of endotracheal aspirate (EA), the former are more expensive and usually require bronchoscopic guidance. $^{(14,17)}$

Worldwide, EA is used in order to diagnosis VAP and can be more cost-effective, making it especially useful in low-resource settings. In order to improve its specificity, there is a need for a method able to differentiate between colonization and infection. The evaluation of antibody-coated bacteria (ACB) is a promising candidate that has already been applied in other areas. ${ }^{(18)}$ Therefore, 
our hypothesis was that $A C B$ would be more prevalent in EA samples from patients with VAP than in those from patients without. In addition, we sought to investigate whether this difference could be used to increase the specificity of the VAP diagnosis.

\section{METHODS}

We conducted a diagnostic case-control study ${ }^{(19)}$ in the general ICU of the Santa Casa de Misericórdia de São Paulo, an academic tertiary care hospital in the city of São Paulo, Brazil. The study was approved by the local research ethics committee. Family members or legal guardians of all of the participating patients gave written informed consent.

Eligible patients were adults (> 18 years of age) who were admitted to the ICU, were undergoing orotracheal intubation with mechanical ventilation, and had neither been diagnosed with nor were under suspicion of having pneumonia at ICU admission.

\section{Case definition}

We defined cases of VAP as those meeting clinical and microbiological criteria. The clinical criteria were signs or symptoms suggestive of pneumonia-new or progressive radiographic infiltrate plus at least two of the following after $48 \mathrm{~h}$ of mechanical ventilation: temperature $>38^{\circ} \mathrm{C}$ or $<36^{\circ} \mathrm{C}$; leukocytosis or leukopenia; and purulent secretions-without any signs or symptoms of other infections. The microbiological criterion was a positive quantitative culture $\left(\geq 10^{5}\right.$ $\mathrm{CFU} / \mathrm{mL}$ ) of an EA sample collected with the standard technique. ${ }^{(9)}$ The EA samples were collected before the introduction of a new antibiotic. Samples were considered representative of lower respiratory tract secretions if they contained $>25$ polymorphonuclear neutrophils and $<10$ squamous epithelial cells/ low-power field.

\section{Control definition}

Patients to compose a control group were selected on a $1: 1$ basis, with concurrent sampling. ${ }^{(20)}$ We selected mechanically ventilated patients who showed no clinical, biochemical, or microbiological evidence of infection at the time of diagnosis and enrolment of the cases. Patients eligible for enrolment in the control group were followed for one week and were selected only if they were not under suspicion of infection during that time. After selection, an EA sample (for culture and $\mathrm{ACB}$ evaluation) was collected from each patient in the control group. We then categorized the control group EA culture results as colonization or negative, depending on whether the cultures grew $\geq 10^{5} \mathrm{CFU} /$ $\mathrm{mL}$ or $<10^{5} \mathrm{CFU} / \mathrm{mL}$.

\section{Respiratory sample preparation}

The EA samples were collected into two sterile tubes. One tube was delivered to the microbiology laboratory, and the other was delivered to the immunology laboratory. To perform the ACB evaluation, one milliliter of the aspirate from each sample was utilized. The samples were washed at $300 \mathrm{~g}$ for $15 \mathrm{~min}$, the supernatant was discarded, and the sediment was washed twice with $0.9 \%$ saline solution. After the final wash, $100 \mu \mathrm{L}$ of the sediment was diluted to $1: 5$ with $0.9 \%$ saline solution, because excessive mucus could hinder the visualization of bacteria and the reading of the culture.

To investigate the $A C B$, four assays were performed: with three monoclonal antibodies, against IgA (antiIgA), IgM (anti-IgM), and IgG (anti-IgG), respectively; and with one polyvalent antibody, against all three. All of the antibodies were conjugated with FITC (Sigma BioSciences, St. Louis, MO, USA). A 1:20 dilution of the antibodies was prepared with Hanks balanced salt solution. The samples obtained were then placed in microtubes: $100 \mu \mathrm{L}$ of the tracheal secretion plus 20 $\mu \mathrm{L}$ of the antibody (anti-IgA, anti-IgM, anti-IgG, or the polyvalent antibody). The assays were incubated at $37^{\circ} \mathrm{C}$ for $15 \mathrm{~min}$ in total darkness, after which they were washed twice, by centrifugation, with Hanks balanced salt solution. Subsequently, we pipetted 15 $\mu \mathrm{L}$ of the solution, using pipettes with sterile tips, and spread the solution over an area corresponding to one coverslip $(24 \times 24 \mathrm{~mm})$. The slides were previously sterilized in a Bunsen burner and covered with sterile cover glass. For the staining, the conventional Gram technique was utilized. All assays were performed in duplicate, and the readers were blinded to whether the sample was from a case or a control.

Each assay was standardized to allow the reader to count 80 bacteria in three or four fields. To detect ACB coated with the FITC-conjugated monoclonal or polyvalent antibodies (four ACB classes), immunofluorescence microscopy was used. The proportion of $A C B$, among the fixed number of 80 bacteria, was then determined. The unspecific immunofluorescence in microorganisms was determined from bacterial incubation with unrelated FITC-conjugated antibodies.

\section{Statistical analysis}

Continuous data are presented as mean \pm standard deviation or as median and interquartile range, as appropriate. Categorical variables are presented as absolute and relative frequencies. To compare the characteristics of the cases and controls, we used the Mann-Whitney test or unpaired t-tests for continuous variables, whereas we used Fisher's exact test or chi-square tests for dichotomous variables. For comparisons among the categories of culture results (negative, colonization, and VAP), we used the Kruskal-Wallis test, with post-hoc comparison by the Mann-Whitney test with Bonferroni correction. Sensitivity, specificity, the positive likelihood ratio, and the negative likelihood ratio were calculated using the standard formulas. We did not calculate positive or negative predictive values, because of the case-control design. To evaluate the overall performance of $A C B$ quantification in the diagnosis of VAP, we used an interactive dot diagram, and the best cut-off for the ACB proportion was established by maximizing the 
sensitivity and specificity. All statistical analyses were performed with statistical program $R$, version 3.1.1 ( $R$ Development Core Team, http://www.r-project.org/).

\section{RESULTS}

We enrolled 45 patients ( 22 cases and 23 controls). The two groups were comparable regarding demographic characteristics (except for gender), comorbidities, and reason for ICU admission (Table 1). At diagnosis, 9 $(41 \%)$ of the 22 patients with VAP presented with sepsis, $10(46 \%)$ presented with severe sepsis, and $3(13 \%)$ presented with septic shock.

\section{Gram-staining and culture results}

The results of the microbiological evaluation of the EA samples are shown in Table 2 . Stained bacteria were observed in all cases and controls, the occurrence of gram-negative and gram-positive bacteria being comparable between the two groups. However, the proportion of patients testing positive for both gram-positive and gram-negative bacteria was significantly higher in the VAP group ( $96 \%$ vs. $65 \% ; p=0.02$ ).

The EA culture results are shown in Table 2. Among the cases, VAP was found to be caused by gram-positive pathogens in 10 patients (46\%), by gram-negative pathogens in $5(23 \%)$, and by more than one pathogen in $7(32 \%)$. Among the controls, the culture results were negative in 11 patients (48\%) and positive (interpreted as colonization) in $12(52 \%)$, of whom $2(17 \%)$ tested positive for gram-positive bacteria, 7
(58\%) tested positive for gram-negative bacteria, and $3(25 \%)$ tested positive for both.

Table 3 shows the gram staining and culture results for each patient. The most common gram-positive pathogen was Staphylococcus aureus, and the most common gram-negative pathogen was Klebsiella pneumoniae.

\section{Immunological evaluation}

The median proportion of $A C B$ was significantly higher among the patients with VAP than among those without, for all ACB classes: IgA ACB-60.6\% (54.7-65.3\%) vs. $22.5 \%(17.5-26.3 \%), \mathrm{p}<0.001 ;$ IgM ACB $-42.5 \%$ (35.6-46.3\%) vs. $12.5 \%(7.5-16.3 \%), p<0.001 ;$ IgG ACB $-50.6 \%$ (43.1-59.1\%) vs. $17.5 \%(13.7-22.5 \%)$, $\mathrm{p}<0.001$; and polyvalent $\mathrm{ACB}-75.6 \%(72.5-84.1 \%)$ vs. $33.8 \%(26.3-40.0 \%), p<0.001$. Figure 1 shows the proportions of each ACB class, by culture result category (negative, colonization, and VAP).

\section{Diagnostic performance}

The interactive dot plots are shown in Figure 2. There was good differentiation between the cases and controls regarding all of the $A C B$ classes. By maximizing sensitivity and specificity, we achieved an accuracy higher than $95 \%$ for all ACB classes except for the polyvalent ACB class. The complete diagnostic evaluation is shown in Table 4.

\section{DISCUSSION}

Our study showed that ACB evaluation in EA samples seems to be a useful tool to facilitate the diagnosis of

Table 1. Demographic characteristics, type of admission, comorbidities, and reason for ICU admission among cases of ventilator-associated pneumonia and controls.

\begin{tabular}{|c|c|c|c|}
\hline Variable & $\begin{array}{l}\text { VAP group } \\
(n=22)\end{array}$ & $\begin{array}{l}\text { Control group } \\
\quad(n=23)\end{array}$ & $\mathbf{p}$ \\
\hline \multicolumn{4}{|l|}{ Demographic characteristics } \\
\hline Age (in years), mean \pm SD & $53 \pm 18$ & $55 \pm 21$ & 0.71 \\
\hline Male gender, n (\%) & $10(46)$ & $19(83)$ & 0.02 \\
\hline Type of admission, $\mathrm{n}(\%)$ & & & 0.18 \\
\hline Surgical & $9(41)$ & $15(65)$ & \\
\hline Medical & $13(59)$ & $8(35)$ & \\
\hline \multicolumn{4}{|l|}{ Comorbidities, n (\%) } \\
\hline Hypertension & $3(14)$ & $7(30)$ & 0.28 \\
\hline Diabetes mellitus & $2(9)$ & $6(26)$ & 0.24 \\
\hline Chronic renal failure & $2(9)$ & $1(4)$ & 0.61 \\
\hline Chronic heart failure & $2(9)$ & $1(4)$ & 0.61 \\
\hline COPD & $3(14)$ & $1(4)$ & 0.35 \\
\hline Cancer & $1(5)$ & $2(9)$ & $>0.99$ \\
\hline Reason for ICU admission, n (\%) & & & 0.84 \\
\hline Postoperative care & $4(18)$ & $5(22)$ & \\
\hline Multiple trauma & $4(18)$ & $5(22)$ & \\
\hline Neurosurgical & $2(9)$ & $4(17)$ & \\
\hline Renal failure $^{a}$ & $4(18)$ & $2(9)$ & \\
\hline Stroke & $2(9)$ & $3(13)$ & \\
\hline Acute coronary syndrome & $3(14)$ & $1(4)$ & \\
\hline Other & $3(14)$ & $3(13)$ & \\
\hline
\end{tabular}

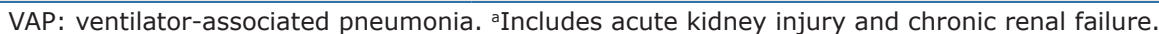


Table 2. Gram-staining and culture results for tracheal aspirate samples among cases of ventilator-associated pneumonia and controls.

\begin{tabular}{|c|c|c|c|}
\hline Variable & $\begin{array}{l}\text { VAP group } \\
(n=22)\end{array}$ & $\begin{array}{l}\text { Control group } \\
\qquad(n=23)\end{array}$ & $\mathbf{p}$ \\
\hline \multicolumn{4}{|l|}{ Gram staining, $\mathrm{n}(\%)$} \\
\hline Presence of bacteria & $22(100)$ & $23(100)$ & $>0.99$ \\
\hline Gram-negative bacteria & $22(100)$ & $21(91)$ & 0.49 \\
\hline Gram-positive bacteria & $21(96)$ & $17(74)$ & 0.10 \\
\hline Gram-negative and gram-positive bacteria & $21(96)$ & $15(65)$ & 0.02 \\
\hline Cultures, n (\%) & & & $<0.01$ \\
\hline Negative & - & $11(48)$ & \\
\hline \multicolumn{4}{|l|}{ Positive } \\
\hline Gram-positive bacteria & $10(45)$ & $2(9)$ & \\
\hline Gram-negative bacteria & $5(23)$ & $7(30)$ & \\
\hline Polymicrobial & $7(32)$ & $3(13)$ & \\
\hline Final interpretation & & & $<0.01$ \\
\hline Negative & - & $11(48)$ & \\
\hline Colonization & - & $12(52)$ & \\
\hline Gram-positive pneumonia & $10(45)$ & - & \\
\hline Gram-negative pneumonia & $5(23)$ & - & \\
\hline Polymicrobial pneumonia & $7(32)$ & - & \\
\hline
\end{tabular}

VAP: ventilator-associated pneumonia.

VAP. In fact, in this controlled setting, higher proportions of ACB were more prevalent in samples from patients with clinically and microbiologically confirmed VAP than in those from patients with colonization only (positive culture without any clinical sign suggestive of VAP) or with negative culture results. In addition, the evaluation of ACB in EA samples showed good performance as an adjunctive tool to differentiate between patients with and without VAP.

There have been few studies evaluating the role of ACB in the diagnosis of pneumonia in mechanically ventilated patients. In 1991, Wunderink et al.(21) analyzed ACB in 71 samples from 36 mechanically ventilated patients. The authors reported that a cut-off value of $\geq 5$ ACB per immersion field had a sensitivity of $52 \%$ (11 of 21 results) and a specificity of $100 \%$ (11 of 11 results). Other small studies have reported that ACB evaluation performs well in the diagnosis of respiratory infections. ${ }^{(22-24)}$ It is difficult to compare the findings of previous studies with those of our study, because of methodological differences, such as including patients not on mechanical ventilation and evaluating patients with community-acquired pneumonia as well as those with hospital-acquired pneumonia.

The microbiologic diagnosis of VAP is based on the quantification of the number of colony-forming units in samples obtained from the lower respiratory tract, although semi-quantitative evaluation has been used with comparable results. ${ }^{(4,9,25)}$ The use of ACB evaluation in the diagnosis of VAP has important potential advantages, such as improving the specificity of a positive EA sample culture, thereby decreasing the proportion of false-positive results. In addition, $A C B$ evaluation seems to be useful in differentiating between colonization and active infection. If we assume that all of the cases (those meeting the clinical and microbiological criteria for VAP) in the present study were "true" infections, evaluating ACB in EA seemed to facilitate the diagnosis of colonization (based on a positive EA culture in the absence of VAP), because ACB proportions were much lower than in "true" infection. Based on the theoretical rational of ACB evaluation, the reliability of the diagnosis should be consistent even when antibiotics have previously been used. (26) We speculate that the evaluation of ACB could help clinicians avoid the use of broad-spectrum antibiotics by reducing the number of false-positive results from EA cultures. It is of note that very few of our patients would have deferred treatment based on the results of the ACB evaluation, because of its high sensitivity.

The evaluation of ACB had been employed in other areas, mainly for urinary tract infections. ${ }^{(18)}$ We hypothesize that this method could be optimized and applied routinely for better evaluation of lower respiratory tract samples. Although new molecular diagnostic methods are available, ${ }^{(27)}$ we speculate that ACB evaluation could be cost-effective, making it particularly useful in low-resource settings. In fact, after standardization, it could be incorporated into the laboratory routine and, by avoiding false-positives, decrease the associated costs of antibiotics and their side effects (for example, a higher incidence of Clostridium infections). ${ }^{\text {(7) }}$ Similar approaches have been applied in the diagnosis of tuberculosis, such as the diagnostic performance of sputum smear evaluation enhanced by fluorescence microscopy as an alternative for use in low-resource settings. ${ }^{(28)}$

Other methods have been used in order to improve the diagnostic accuracy of clinical and microbiological criteria. Such methods have comprised the use of the currently available biomarkers, such as C-reactive protein (CRP) and procalcitonin. $(29,30)$ For instance, one 
Table 3. Gram-staining and culture results, by patient, among cases of ventilator-associated pneumonia and controls.

\begin{tabular}{|c|c|c|c|c|c|c|}
\hline \multirow[t]{2}{*}{ Case } & \multicolumn{3}{|c|}{ VAP group } & \multicolumn{3}{|c|}{ Control group } \\
\hline & $\begin{array}{l}\text { Gram-positive } \\
\text { staining }\end{array}$ & $\begin{array}{l}\text { Gram-negative } \\
\text { staining }\end{array}$ & Isolate(s) & $\begin{array}{l}\text { Gram-positive } \\
\text { staining }\end{array}$ & $\begin{array}{l}\text { Gram-negative } \\
\text { staining }\end{array}$ & Isolate(s) \\
\hline 1 & Yes & Yes & $\begin{array}{c}\text { Staphylococcus } \\
\text { aureus }\end{array}$ & No & Yes & $\begin{array}{l}\text { Klebsiella } \\
\text { pneumoniae }\end{array}$ \\
\hline 2 & No & Yes & Enterobacter sp. & No & Yes & - \\
\hline 3 & Yes & Yes & S. aureus & Yes & Yes & - \\
\hline 4 & Yes & Yes & S. aureus & Yes & Yes & $\begin{array}{l}\text { Enterococcus } \\
\text { faecalis }\end{array}$ \\
\hline 5 & Yes & Yes & $\begin{array}{l}\text { S. aureus \& } K \text {. } \\
\text { pneumoniae }\end{array}$ & Yes & Yes & K. pneumoniae \\
\hline 6 & Yes & Yes & $\begin{array}{l}\text { S. aureus \& } E . \\
\text { faecalis }\end{array}$ & Yes & Yes & $\begin{array}{l}\text { K. pneumoniae \& } \\
\text { Proteus mirabilis }\end{array}$ \\
\hline 7 & Yes & Yes & S. aureus & Yes & Yes & - \\
\hline 8 & Yes & Yes & S. aureus & Yes & Yes & $\begin{array}{l}\text { Pseudomonas } \\
\text { aeruginosa }\end{array}$ \\
\hline 9 & Yes & Yes & S. aureus & No & Yes & P. aeruginosa \\
\hline 10 & Yes & Yes & S. aureus & Yes & Yes & $\begin{array}{c}\text { Providencia } \\
\text { rettgeri }\end{array}$ \\
\hline 11 & Yes & Yes & $\begin{array}{l}\text { Haemophilus } \\
\text { influenzae }\end{array}$ & Yes & Yes & $\begin{array}{l}\text { S. aureus \& } P \text {. } \\
\text { aeruginosa }\end{array}$ \\
\hline 12 & Yes & Yes & H. influenzae & Yes & Yes & P. rettgeri \\
\hline 13 & Yes & Yes & $\begin{array}{c}\text { S. aureus \& } \\
\text { Enterobacter sp. }\end{array}$ & No & Yes & - \\
\hline 14 & Yes & Yes & S. aureus & Yes & Yes & $\begin{array}{l}\text { S. aureus \& } K \text {. } \\
\text { pneumoniae }\end{array}$ \\
\hline 15 & Yes & Yes & $\begin{array}{l}\text { S. aureus \& } K \text {. } \\
\text { pneumoniae }\end{array}$ & Yes & Yes & - \\
\hline 16 & Yes & Yes & S. aureus & Yes & Yes & - \\
\hline 17 & Yes & Yes & $\begin{array}{l}\text { S. aureus \& } \\
\text { Acinetobacter } \\
\text { baumannii }\end{array}$ & No & Yes & - \\
\hline 18 & Yes & Yes & P. rettgeri & Yes & No & - \\
\hline 19 & Yes & Yes & S. aureus & No & Yes & - \\
\hline 20 & Yes & Yes & K. pneumoniae & Yes & Yes & - \\
\hline 21 & Yes & Yes & $\begin{array}{l}\text { S. aureus \& } K \text {. } \\
\text { pneumoniae }\end{array}$ & Yes & Yes & Klebsiella oxytoca \\
\hline 22 & Yes & Yes & $\begin{array}{l}\text { S. aureus \& } P \text {. } \\
\text { aeruginosa }\end{array}$ & Yes & Yes & - \\
\hline 23 & - & - & - & Yes & No & S. aureus \\
\hline
\end{tabular}

VAP: ventilator-associated pneumonia.

study found a positive association between the serum values of CRP and the bacterial load in EA samples in 68 patients with $\mathrm{VAP}_{,}^{(29)}$ suggesting that CRP values could increase the diagnostic accuracy of EA evaluation in VAP. Other studies have reported that determining the number of intracellular bacteria increases the specificity of respiratory sample evaluation. ${ }^{(15,31)}$ One of the main limitations of our study is the lack of a comparison between ACB evaluation and other methods, which prevented us from assessing whether the diagnostic performance of $A C B$ evaluation differs from that of other reported methods.

The diagnosis of VAP is challenging, mainly because of the lack of a gold standard diagnostic method. In addition, even for research purposes, lung biopsy and tissue culture are not feasible and probably not beneficial. ${ }^{(11,14,32)}$ Furthermore, there has been a debate about whether invasive or noninvasive methods are preferable for obtaining lower respiratory tract samples. In the present study, we decided to assess the microbiologic evaluation by evaluating EA samples. That choice was made due to the unavailability of bronchoscopy at our facility, as well as the difficulties involved in obtaining bronchoscopes and contracting trained staff to operate them. The choice was also pragmatic, because we believe that our facility is representative of the majority of public health care facilities in Brazil and in other low- to middle-resource settings. However, this pragmatic approach could have decreased our ability to study ACB in respiratory samples obtained by invasive methods, which are usually more specific for the diagnosis of lower respiratory tract infections. ${ }^{(2)}$ 

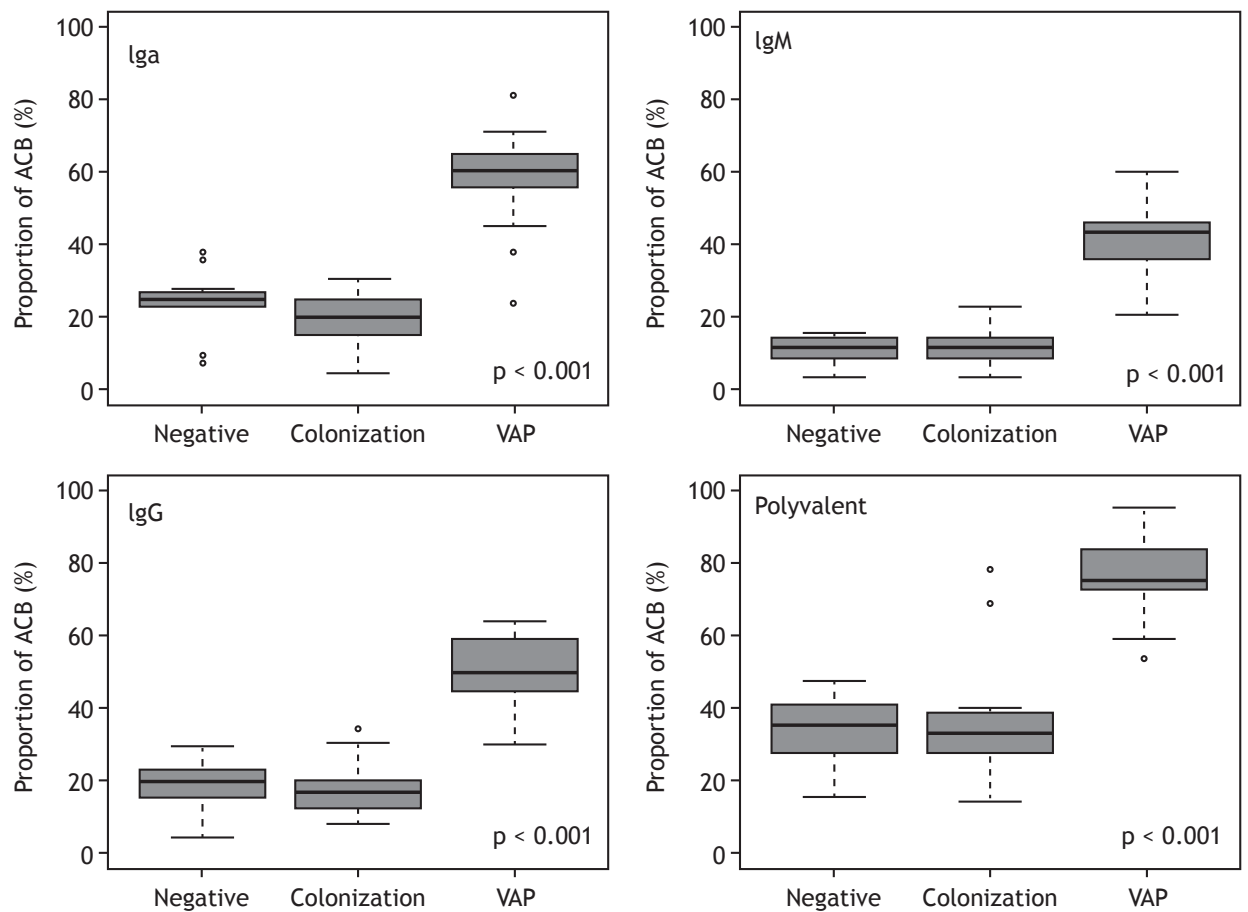

Figure 1. Proportion of antibody-coated bacteria $(A C B)$ in each antibody class among the tracheal aspirate culture result categories: negative, colonization, and ventilator-associated pneumonia (VAP). Values of p refer to the comparison among the three categories (Kruskal-Wallis test). In the post-hoc comparisons, significant differences were observed only for VAP vs. negative and VAP vs. colonization ( $p<0.001$ for both). Patients in the control group were divided between the negative and colonization ( $\geq 10^{5} \mathrm{CFU} / \mathrm{mL}$ ) categories. The VAP category comprises all cases (patients who met the clinical and microbiological criteria for VAP).
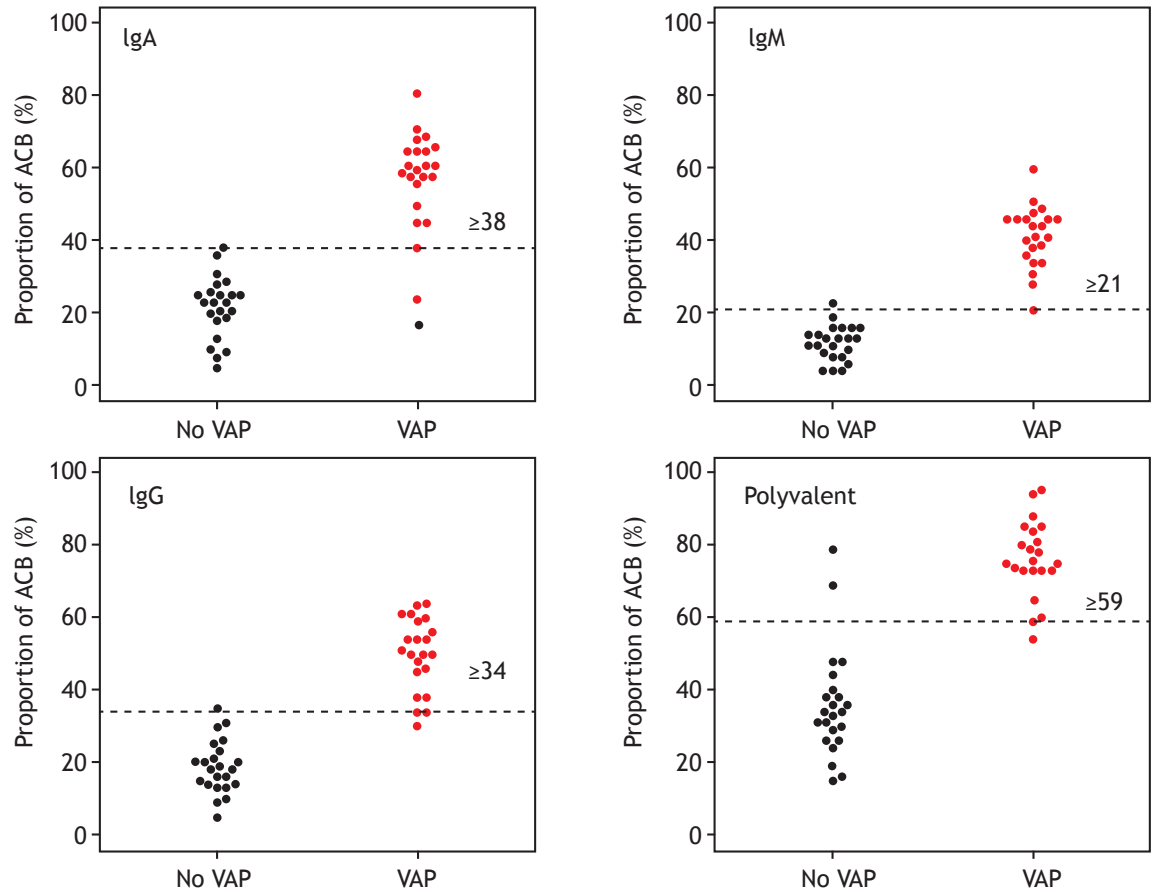

Figure 2. Interactive dot plot for the performance of antibody-coated bacteria (ACB) evaluation, by antibody class, in the diagnosis of ventilator-associated pneumonia (VAP). Horizontal dotted lines denote the best cut-off values to maximize sensitivity and specificity for each antibody class. 
Table 4. Diagnostic performance of each class of antibody-coated bacteria in differentiating between cases of ventilatorassociated pneumonia and controls.

\begin{tabular}{lcccccc} 
ACB class & Cut-off & Sensitivity & Specificity & Accuracy & LR + & LR - \\
IgA & $\geq 38 \%$ & $95.5 \%$ & $95.7 \%$ & $95.6 \%$ & 21.96 & 0.05 \\
$\operatorname{lgM}$ & $\geq 21 \%$ & $100.0 \%$ & $95.7 \%$ & $97.8 \%$ & 23.00 & - \\
$\operatorname{lgG}$ & $\geq 34 \%$ & $95.5 \%$ & $95.7 \%$ & $95.6 \%$ & 21.96 & 0.05 \\
Polyvalent & $\geq 54 \%$ & $95.5 \%$ & $91.3 \%$ & $93.3 \%$ & 10.98 & 0.05 \\
\hline
\end{tabular}

ACB: antibody-coated bacteria; LR+: positive likelihood ratio; and LR-: negative likelihood ratio.

This study has other limitations. Although it was a single-center diagnostic case-control study, we rigorously selected our cases and controls, which has advantages such as increasing the chances of identifying "true" cases of VAP and controls without any suspicion of infection. However, because of those restrictions, it is likely that the performance of ACB in the diagnosis of VAP would be different in other settings and designs. Nevertheless, diagnostic case-control studies are useful in the preliminary phase of diagnostic tests. ${ }^{(19)}$ This study design also prevented us from evaluating the impact of $A C B$ in patients under clinical suspicion of VAP but with negative EA sample culture. We also had no access to the exact numbers of colony-forming units in the EA sample cultures, because we quantified them in a binary manner $\left(<10^{5}\right.$ or $\geq 10^{5} \mathrm{CFU} / \mathrm{mL}$ ).
Therefore, we could not correlate the bacterial burden with the proportion of ACB. Finally, we did not evaluate other variables that could modulate the diagnostic performance, such as the use of antibiotics and corticosteroids. ${ }^{(33)}$

In conclusion, we observed a significantly higher number of $A C B$ in patients with VAP than in those without. We believe that ACB evaluation could be used in order to improve the specificity of the diagnosis of VAP, which is needed given the challenge of achieving a reliable diagnosis in that context. Further research in this field is warranted, because ACB evaluation could be cost-effective and therefore useful in low-resource settings, having the advantages of decreasing the number of false-positive results and reducing the rate of overtreatment.

\section{REFERENCES}

1. Woske HJ, Röding T, Schulz I, Lode H. Ventilator-associated pneumonia in a surgical intensive care unit: epidemiology, etiology and comparison of three bronchoscopic methods for microbiological specimen sampling. Crit Care. 2001;5(3):167-73. http://dx.doi. org/10.1186/cc1017

2. Chastre J, Fagon JY. Ventilator-associated pneumonia. Am J Respir Crit Care Med. 2002;165(7):867-903. http://dx.doi.org/10.1164/ ajrccm.165.7.2105078

3. Fagon JY, Chastre J, Wolff M, Gervais C, Parer-Aubas S, Stéphan $\mathrm{F}$, et al. Invasive and noninvasive strategies for management of suspected ventilator-associated pneumonia. A randomized trial. Ann Intern Med. 2000;132(8):621-30. http://dx.doi.org/10.7326/00034819-132-8-200004180-00004

4. Lisboa T, Rello J. Diagnosis of ventilator-associated pneumonia: is there a gold standard and a simple approach? Curr Opin Infect Dis. 2008;21(2):174-8. http://dx.doi.org/10.1097/0CO.0b013e3282f55dd1

5. Bekaert M, Timsit JF, Vansteelandt S, Depuydt P, Vésin A, GarrousteOrgeas $M$, et al. Attributable mortality of ventilator-associated pneumonia: a reappraisal using causal analysis. Am J Respir Crit Care Med. 2011;184(10):1133-9. http://dx.doi.org/10.1164/rccm.20110508670C

6. Giunta V, Ferrer M, Esperatti M, Ranzani OT, Saucedo LM, Li Bassi $\mathrm{G}$, et al. ICU-acquired pneumonia with or without etiologic diagnosis: a comparison of outcomes. Crit Care Med. 2013:41(9):2133-43. http://dx.doi.org/10.1097/CCM.0b013e31828a453b

7. Kollef $\mathrm{MH}$, Hamilton $\mathrm{CW}$, Ernst FR. Economic impact of ventilatorassociated pneumonia in a large matched cohort. Infect Control Hosp Epidemiol. 2012;33(3):250-6. http://dx.doi.org/10.1086/664049

8. Rodrigues PM, Carmo Neto Ed, Santos LR, Knibel MF. Ventilatorassociated pneumonia: epidemiology and impact on the clinical evolution of ICU patients. J Bras Pneumol. 2009;35(11):1084-91. http://dx.doi.org/10.1590/S1806-37132009001100005

9. American Thoracic Society; Infectious Diseases Society of America Guidelines for the management of adults with hospital-acquired, ventilator-associated, and healthcare-associated pneumonia. Am J Respir Crit Care Med. 2005;171(4):388-416. http://dx.doi. org/10.1164/rccm.200405-644ST

10. Torres A, el-Ebiary M. Invasive diagnostic techniques for pneumonia: protected specimen brush, bronchoalveolar lavage, and lung biopsy methods. Infect Dis Clin North Am. 1998;12(3):701-22. http://dx.doi. org/10.1016/S0891-5520(05)70206-3
11. Klompas M. Does this patient have ventilator-associated pneumonia? JAMA. 2007;297(14):1583-93. http://dx.doi.org/10.1001/ jama.297.14.1583

12. Ranzani OT, Prina E, Torres A. Nosocomial pneumonia in the intensive care unit: how should treatment failure be predicted? Rev Bras Ter Intensiva. 2014;26(3):208-11. http://dx.doi.org/10.5935/0103$507 X .20140032$

13. Singh N, Falestiny MN, Rogers P, Reed MJ, Pularski J, Norris R, et al. Pulmonary infiltrates in the surgical ICU: prospective assessment of predictors of etiology and mortality. Chest. 1998;114(4):1129-36. http://dx.doi.org/10.1378/chest.114.4.1129

14. Nair GB, Niederman MS. Ventilator-associated pneumonia: present understanding and ongoing debates. Intensive Care Med 2015;41(1):34-48. http://dx.doi.org/10.1007/s00134-014-3564-5

15. Correa Rde A, Luna CM, Anjos JC, Barbosa EA, Rezende CJ Rezende AP, et al. Quantitative culture of endotracheal aspirate and BAL fluid samples in the management of patients with ventilator-associated pneumonia: a randomized clinical trial. J Bras Pneumol. 2014;40(6):643-51. http://dx.doi.org/10.1590/S180637132014000600008

16. Berton DC, Kalil AC, Teixeira PJ. Quantitative versus qualitative cultures of respiratory secretions for clinical outcomes in patients with ventilator-associated pneumonia. Cochrane Database Syst Rev. 2014;10:CD006482. http://dx.doi.org/10.1002/14651858.cd006482. pub4

17. Carvalho MV, Winkeler GF, Costa FA, Bandeira TJ, Pereira ED, Holanda MA. Concordance between tracheal aspirate and bronchoalveolar lavage in the diagnosis of ventilator associated pneumonia. J Pneumol. 2004;30(1):26-38. http://dx.doi.org/10.1590/ S1806-37132004000100007

18. Falkenhagen $U$, Hacker $K$, Rehbock $A$, Handschuck I, Nimmich W. Incidence of antibody-coated bacteria in patients with chronic pyelonephritis [Article in German]. Z Urol Nephrol. 1986;79(11):60918.

19. Rutjes AW, Reitsma JB, Vandenbroucke JP, Glas AS, Bossuyt PM. Case-control and two-gate designs in diagnostic accuracy studies. Clin Chem. 2005;51(8):1335-41. http://dx.doi.org/10.1373/ clinchem.2005.048595

20. Vandenbroucke JP, Pearce N. Case-control studies: basic concepts Int J Epidemiol. 2012;41(5):1480-9. http://dx.doi.org/10.1093/ije/ dys 147 
21. Wunderink RG, Russell GB, Mezger E, Adams D, Popovich J $\mathrm{Jr}$. The diagnostic utility of the antibody-coated bacteria test in intubated patients. Chest. 1991;99(1):84-8. http://dx.doi.org/10.1378/ chest.99.1.84

22. Sala-Mateus $C$, Lloveras $P$, Barber E, Puig de la Bellacasa J, Torres $A$ Jiménez de Anta MT, et al. Antibody-coated bacteria and quantitative culture in sputum samples from patients with bronchiectasis [Article in Spanish]. Enferm Infecc Microbiol Clin. 1990;8(9):568-71.

23. Winterbauer $\mathrm{RH}$, Hutchinson JF, Reinhardt GN, Sumida SE, Dearden $\mathrm{B}$, Thomas CA, et al. The use of quantitative cultures and antibody coating of bacteria to diagnose bacterial pneumonia by fiberoptic bronchoscopy. Am Rev Respir Dis. 1983;128(1):98-103. http://dx.doi. org/10.1164/arrd.1983.128.1.98

24. Matsumoto T, Kaku M, Tateda K, Furuya N, Hirakata Y, Yamaguch K. Detection of antibody-coated bacteria in expectorated sputum for diagnosis of lower respiratory infections. Microbiol Immunol. 1994;38(4):287-93. $\quad$ http://dx.doi.org/10.1111//.1348-0421.1994. tb01778.x

25. Camargo LF, De Marco FV, Barbas CS, Hoelz C, Bueno MA Rodrigues $\mathrm{M}$ Jr, et al. Ventilator associated pneumonia: comparison between quantitative and qualitative cultures of tracheal aspirates. Crit Care. 2004;8(6):R422-30. http://dx.doi.org/10.1186/cc2965

26. Torres A, González J, Ferrer M. Evaluation of the available invasive and non-invasive techniques for diagnosing nosocomial pneumonias in mechanically ventilated patients. Intensive Care Med. 1991:17(8):439-48. http://dx.doi.org/10.1007/BF01690764

27. Lung M, Codina G. Molecular diagnosis in HAPNAP. Curr Opin Crit Care. 2012:18(5):487-94. http://dx.doi.org/10.1097/ MCC.0b013e3283577d37
28. Steingart KR, Henry M, Ng V, Hopewell PC, Ramsay A, Cunningham $J$, et al. Fluorescence versus conventional sputum smear microscopy for tuberculosis: a systematic review. Lancet Infect Dis. 2006;6(9):570-81. Erratum in: Lancet Infect Dis. 2006;6(10):628. http://dx.doi.org/10.1016/S1473-3099(06)70578-3

29. Lisboa T, Seligman R, Diaz E, Rodriguez A, Teixeira PJ, Rello J. C-reactive protein correlates with bacterial load and appropriate antibiotic therapy in suspected ventilator-associated pneumonia Crit Care Med. 2008;36(1):166-71. http://dx.doi.org/10.1097/01. CCM.0000297886.32564.CF

30. Ramirez P, Garcia MA, Ferrer M, Aznar J, Valencia M, Sahuquillo JM et al. Sequential measurements of procalcitonin levels in diagnosing ventilator-associated pneumonia. Eur Respir J. 2008;31(2):356-62. http://dx.doi.org/10.1183/09031936.00086707

31. Torres A, El-Ebiary M, Fábregas N, González J, de la Bellacasa JP, Hernández $\mathrm{C}$, et al. Value of intracellular bacteria detection in the diagnosis of ventilator associated pneumonia. Thorax. 1996;51(4):378-84. http://dx.doi.org/10.1136/thx.51.4.378

32. Torres A, Fàbregas N, Ewig S, de la Bellacasa JP, Bauer TT, Ramirez J. Sampling methods for ventilator-associated pneumonia: validation using different histologic and microbiological references. Crit Care Med. 2000;28(8):2799-804. http://dx.doi.org/10.1097/00003246200008000-00020

33. Ranzani OT, Ferrer M, Esperatti M, Giunta V, Bassi GL, Carvalho $\mathrm{CR}$, et al. Association between systemic corticosteroids and outcomes of intensive care unit-acquired pneumonia. Crit Care Med. 2012;40(9):2552-61. http://dx.doi.org/10.1097/ CCM.0b013e318259203d 